\title{
Value Creation in Collaborative Networks: The Case of RFiD Implementation
}

\author{
Carine Dominguez ${ }^{1, *}$, Blandine Ageron ${ }^{2}$, and Gilles Neubert ${ }^{3}$ \\ ${ }^{1}$ Carine Dominguez, University Jean Monnet, Coactis laboratory, 6 rue basse des rives \\ 42023 Saint-Etienne, France \\ carine.dominguez@univ-st-etienne.fr \\ ${ }^{2}$ Blandine Ageron, Université de Grenoble, CERAG laboratory, IUT Valence, \\ Rue Barthelemy de Laffemas, 26000 Valence, France \\ ${ }^{3}$ Gilles Neubert, LIESP Laboratory, Saint-Etienne Business School, \\ 51-53 Cours Fauriel, 42009 Saint Etienne, France
}

\begin{abstract}
In this article, we question the way CNs are built around the implementation of RFiD in a supply chain and what are the value creation logics among these CNs. We address three main questions: the way and types of CNs in a RFiD implementation project, the nature of the aggregator and value creation of each actor during the different phases of the project and finally the interconnections between $\mathrm{CNs}$ in the value creation logic. We provide answers to theses questions based on a case study that describes the implementation of the RFiD innovative technology in a jewellery supply chain.
\end{abstract}

Keywords: collaborative networks, supply chain, RFiD, value generator, value creation.

\section{Introduction}

There are different forms of collaborative networks. In this article, we question the way CNs are built dynamically around the implementation of RFiD in a supply chain and what are the value creation logics among these CNs.

To do so, we observe the dynamic construction of three types of collaborative networks (CNs) that emerge with the implementation of RFiD in jewellery products. At each phase of the RFiD project, we aim at understanding the value generator (investment in the collaboration) and value creation (gains) of each actor. We also question the interconnections of value creation between different $\mathrm{CNs}$ based on the fact the RFiD impact studies to date largely focus on a single firm setting. This leads to characterise the specificity of collaboration of each network and the type of value created in this project. We finally open the discussion on the appropriate models that could describe how to create value in RFiD supply chain projects via the different RFiD CNs.

\footnotetext{
* Corresponding author.
} 


\subsection{Inter-organizational Information Systems Supporting Collaborative Networks}

[5] define a collaborative network (CN) is constituted by a variety of entities (organizations and people) that are largely autonomous, geographically distributed, and heterogeneous in terms of their: operating environment, culture, social capital and goals. Nevertheless these entities collaborate to better achieve common or compatible goals, and whose interactions are supported by inter-organizational information systems. Different forms of collaborative network organizations (CNOs) can be distinguished in the literature [6] from temporary networks that are goal-oriented (virtual organizations and teams, dynamic supply chains, virtual government) to more long-term strategic networks (virtual organization breeding environment, clusters, business ecosystems, supply chains, districts) that remain relatively stable with a clear definition of members' roles along the value chain.

Supply chains are specific CNOs defined as a network of organizations interlinking suppliers, manufacturers and distributors in the different processes and activities that produce value in the form of products and services delivered to end customer [7].

Given the dynamic and often temporary nature of CNs, it is important to understand their life cycle that can be describe into five main steps [6]: creation, operation, evolution, dissolution and metamorphosis.

Traditionally, the main inter organizational information systems supporting products in the supply chain are bar codes linked to EDI [14]. One of the key requirements of temporary $\mathrm{CN}$ is to develop a generic Information System to control the interoperability of the participating organizations, distributed, heterogeneous and concurrent systems for the purpose of accessing and sharing the necessary data and resources. Because temporary $\mathrm{CNs}$ are short terms alliances, formed to address fast-changing opportunities, they should be connected to the IS of the long-term $\mathrm{CN}$ via "plug-andplay" options [1]. RFiD technology is emerging in order to improve process efficiency, notably by reducing daily receipts and inventories [26].

\subsection{Collaborative Networks around RFiD in a Supply Chain}

Supply chain collaboration implies that the chain members become involved in coordinating activities that span boundaries of their organizations in order to fulfil end users needs [2]. According to [24], the intensity of collaboration depends on the following impact horizons: Short-term, medium-term or long-term.

Collaboration between supply chain partners has been covered extensively in the strategic management literature ([2]; [15]; [11]; [3]). Several research surveys have shown that improvement of inter-enterprise processes is one of the major issues in Supply Chain Management [4]. [13] have recognised that the application of information technology in the supply chain management has become one of a major issue of both managers and researchers, as Information technology improve the performance of both individual firm and supply chain as a whole. Information technology plays major role in various supply chain collaboration practices as it enables and integrates information exchanges between supply chain partners. In this context, EDI, Internet, standards and others technologies have been developed in order to support increasing exchanges. By the same time, new collaborative practices emerge between supply 
chain partners, such as Vendor/Supplier management inventory, Collaborative Planning, Forecasting and Replenishment (CPFR). And as the volume of information exchanged and the intensity of interactions between partners further increased, there has been an amplified requirement towards an adequate underlying technology infrastructure. In order to cope with these new collaboration practices, new ways of information exchanges have emerged [23].

The recent industry report CGI [10] emphasizes the new collaborative processes that will be empowered through the use of RFID. The emergence of these new technologies revolutionize many of the supply chain operations by reducing costs, improving service levels, etc [26].

\subsection{Value Creation in RFiD Collaborative Networks}

Different value generators have been highlighted in the literature. [22] propose main value generators in CNs that are good indicators of the metric of the collaboration: physical and financial assets, human, organizational and relational capital.

Finally, there are both tangible and intangible types of benefits that can be reached with RFiD in a manufacturing process [16]. The main benefits are production planning, process optimization, IT management, improving quality and customer service, increasing reputation and improving inter organizational collaboration.

RFID provides multiple benefits for the supply-chain. It can add value along the entire supply-chain and related logistical operations and business relationships for more effective business process design. It provides a means of tracking supplier items from supplier through the distribution network to the point of consumption. The possibilities of RFID let its use in the supply-chain somewhat transformational ([20]; [9]) have identified the four main processes that can be directly affected by RFID.

Finally, the logic of value creation in these networks included different layers. While the layers may embrace sequential activity chains, other co-producing value creation activities will also take place in parallel, further enhancing value creation at the network level [1]. The notion of value creation is central to strategic management theory and includes value not only in supply and IS flows but also on knowledge sharing, learning and innovation [17] in what can be labelled strategic supplier networks. Firms acting in different value constellations [21] are characterized by social embeddedness [12], governance mechanism and the development of a sense of trust and reciprocity.

\section{The Case Study Analysis}

The majority of research on RFiD projects has focused on quantitative methodologies and there are very few case studies focusing on the description of the complexity of RFID implementation project in a supply chain such as those developed by [18] and [19]. We conducted a single case study with 15 semi-structured interviews, to reach an in-depth and insight understanding into this contemporary phenomenon [27].

Our case study was performed with one of the main French retailer. The choice of this case study is largely explained by the fact that: 
- The company is a pioneer in the implementation of the RFID technology and no research has been done in France.

- The jewellery supply chain with RFID has never been studied before.

\subsection{Actors Involved in the RFID Project and Chronological Steps}

We can present three main CNs in this project (Fig.1).

- The Product Collaborative Network (PCN): the more stable CN that deals with supplying Casino's stores (POS) with jewellery products. Different actors are part of this CN: suppliers of jewels, the logistics service provider (LSP), Casino's 80 Stores called "Boutique Or".

- The Information System Collaborative Network (ISCN): the network that is in charge of the evolution and maintenance of Casino' IS linked with the jewellery supply chain. Different actors are part of this CN: Casino's CIO (Information Systems Department) and the Information System Service Provider (ISSP)

- The RFiD Collaborative Network (RFiD CN): it is the temporary network that is build with the RFiD project. Different actors are part of this $\mathrm{CN}$ : the label supplier, the printer pupplier: this company proposes printing machines to encode and print the RFiD tags inside the LSP warehouse, the reader supplier and the tag supplier.

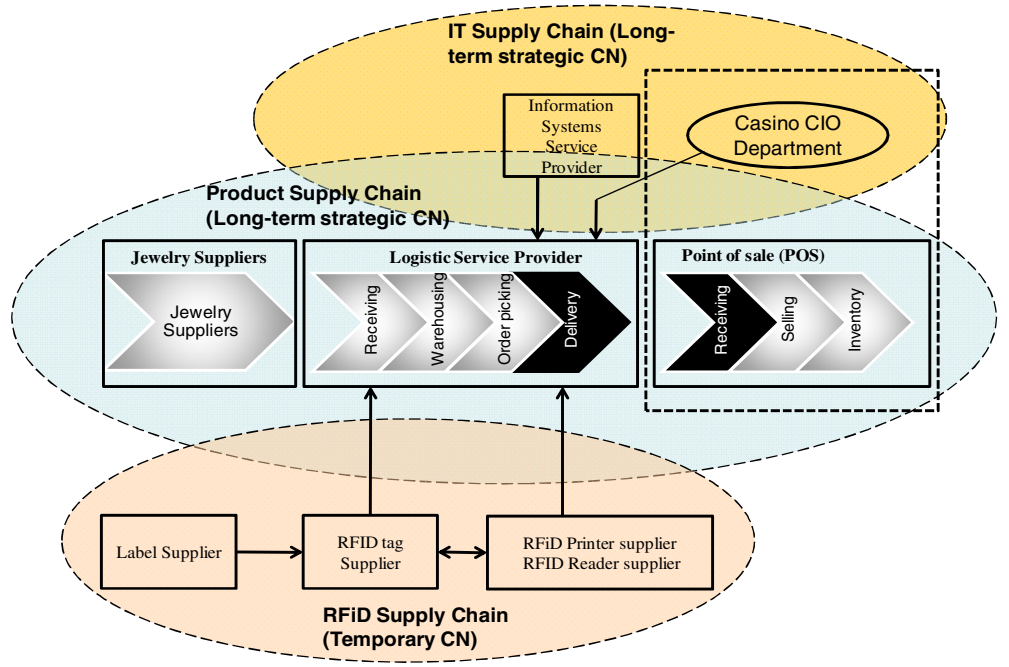

Fig. 1. Temporary and long-term collaborative networks value creation linked with the RFiD project

How had these CNs been built over time? Different logics explain the configuration of these networks. The PCN was the initial and historical one: Casino was working with its LSP to supply jewellery products for many years with bar codes. It is interesting to come back to the main criteria that explain the shaping of theses CNs. 
To do so, let us enter into more details in the description of the phase 1 "seeking opportunities" step 4 (See 3.2.1) and the phase 2 "pilot project and validation" step 7 (See 3.2.2). First, the choice of the ISSP in the IS CN can be surprising as the retailer Casino decided to choose a very small-sized firm with high expertise in IS. Among the different criteria to select an ISSP, the fact that the company that was selected had been working in the past, and for many years, with the LSP brought trust in the relationship. Trust build in the PCN was spread out in the IS CN. Second, the shaping of the RFiD CN did not follow the same logic. Casino sent an invitation to tender to different companies positioned in the RFiD market. Two main RFiD tag suppliers were selected in the final short list and the one that was finally chosen proposed the lower global cost. After that, the RFiD tag supplier managed to convince Casino to work with its own CNS, hence connecting the Label supplier and the RFiD printer and reader supplier.

\subsection{The Case Study Analysis}

In order to analyse the value creation logic in the RFiD project, we use the framework of [9] that we adapt and complete to illustrate our case study. Fosso and Wamba's framework, specifically developed for RFID projects, is composed of a sequence of three main phases that describe a RFID project implementation: opportunities seeking, pilot project and validation and RFID project deployment. In the following section, we will present only phase 1 : Opportunity seeking; phases 2 : Pilot project and validation and phase 3: RFID project development will be discussed later during the session.

\subsubsection{Phase 1: Opportunities Seeking}

This initial phase deals with the opportunities to implement the RFID project in a specific value chain. It is composed of six steps. In the table below, we describe for each phase what actors were involved, what did they do, what type of value they invest in the $\mathrm{CN}$ called value generator [22] and the value created (gains) for each actor in the different CNs.

\begin{tabular}{|l|l|l|l|}
\hline $\begin{array}{c}\text { Phase 1: } \\
\text { Opportunities } \\
\text { seeking }\end{array}$ & \multicolumn{1}{|c|}{$\begin{array}{c}\text { Actors and CNs } \\
\text { involved }\end{array}$} & $\begin{array}{l}\text { Value generator } \\
\text { (investment in the } \\
\text { collaboration) }\end{array}$ & \multicolumn{1}{|c|}{$\begin{array}{c}\text { Value creation } \\
\text { (gains) }\end{array}$} \\
\hline $\begin{array}{l}\text { Step1: Primary } \\
\text { motivation (Why?) }\end{array}$ & $\begin{array}{l}- \text { IS CN: IT consultancy } \\
\text { company came and propose } \\
\text { its services to Casino CIT } \\
\text { - IS CN (Operation): Casino } \\
\text { CIT sees the project as an } \\
\text { opportunity to develop an } \\
\text { innovative technology and } \\
\text { gain visibility inside the } \\
\text { company }\end{array}$ & $\begin{array}{l}\text { - IS CN (CIO): Scanning } \\
\text { the environment and IT } \\
\text { opportunities in business } \\
\text { (Organizational) } \\
- \text { CIO: IS innovation } \\
\text { (Organizational) }\end{array}$ \\
\hline $\begin{array}{l}\text { Step2: Analysis of } \\
\text { the product value } \\
\text { chain (What and } \\
\text { Why?) }\end{array}$ & $\begin{array}{l}\text { - IS CN (Operation): } \\
\text { *CIO was searching for } \\
\text { products disconnected to the } \\
\text { main Casino's IS to lower } \\
\text { risks in case of project } \\
\text { failure }\end{array}$ & $\begin{array}{l}\text { IS CN (CIO): } \\
\text { minimize risks linked } \\
\text { to main IS } \\
\text { Infrastructure } \\
\text { (Physical) }\end{array}$ \\
\hline
\end{tabular}




\begin{tabular}{|c|c|c|c|}
\hline $\begin{array}{l}\text { Step3: } \\
\text { Identification of the } \\
\text { critical activities } \\
\text { (Which?) }\end{array}$ & $\begin{array}{l}\text { - PCN (Operation): LSP in } \\
\text { cooperation with CIT study } \\
\text { the productivity and cost } \\
\text { gains in different processes } \\
\text { and finally hold receiving } \\
\text { and inventories }\end{array}$ & $\begin{array}{l}\text { - PCN: LSP and } \\
\text { Casino POS (Human) }\end{array}$ & $\begin{array}{l}\text { PCN (Casino POS): } \\
\text { identification of SC } \\
\text { activity improvement } \\
\text { opportunities } \\
\text { (Organizational) }\end{array}$ \\
\hline $\begin{array}{l}\text { Step4: Mapping of } \\
\text { the network of } \\
\text { firms supporting } \\
\text { the PVC (Who and } \\
\text { with Whom?) }\end{array}$ & $\begin{array}{l}\text { - IS CN (Evolution): CIO } \\
\text { Casino } \\
\text { - IS RFiD (Creation): CIO }\end{array}$ & $\begin{array}{l}-\quad \text { IS CN } \text { (CIO): } \\
\text { identification of } \\
\text { RFiD competencies } \\
\text { in the market: Infor- } \\
\text { mation Systems LSP, } \\
\text { Label Supplier, RFiD } \\
\text { Tag supplier (Hu- } \\
\text { man) }\end{array}$ & 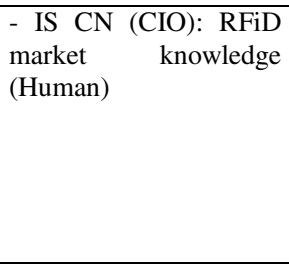 \\
\hline $\begin{array}{l}\text { Step5: Mapping of } \\
\text { intra-organizational } \\
\text { processes for the } \\
\text { identified } \\
\text { opportunities (How } \\
\text { within } \\
\text { organization?) }\end{array}$ & $\begin{array}{l}\text { - IS CN (Evolution): CIO } \\
\text { Casino } \\
\text { - PCN (Evolution): the } \\
\text { jewellery supply chain } \\
\text { foresees potential changes } \\
\text { in its processes with the } \\
\text { introduction of RFiD }\end{array}$ & $\begin{array}{l}\text { - IS CN (Evolution): } \\
\text { CIO Casino is looking } \\
\text { for complementary } \\
\text { competencies } \\
\text { - PCN:LSP: process } \\
\text { modifications to } \\
\text { adapt to Casino POS } \\
\text { demand (Organiza- } \\
\text { tional) }\end{array}$ & $\begin{array}{l}\text {-ISCN (CIO): } \\
\text { competencies } \\
\text { identification: make of } \\
\text { buy decision } \\
\text { - PCN (Casino POS) } \\
\text { identification of SC } \\
\text { process improvement } \\
\text { opportunities } \\
\text { (Organizational) }\end{array}$ \\
\hline $\begin{array}{l}\text { Step6: Mapping of } \\
\text { inter-organizational } \\
\text { processes for the } \\
\text { identified } \\
\text { opportunities (How } \\
\text { between } \\
\text { organization?) }\end{array}$ & $\begin{array}{l}\text { - ISCN (Evolution): CIO } \\
\text { Casino }\end{array}$ & $\begin{array}{l}-\quad \text { ISCN } \quad(\mathrm{CIO}): \\
\text { competencies } \\
\text { identification (make } \\
\text { or buy decision) }\end{array}$ & $\begin{array}{l}\text { - ISCN (CIO): add } \\
\text { complementary } \\
\text { resources outside the } \\
\text { core IS infrastructure } \\
\text { (Relational) }\end{array}$ \\
\hline
\end{tabular}

\subsubsection{Phase 2: Pilot Project and Validation}

The objective of this second phase is to develop a pilot project in order to validate the feasibility of the RFID implementation. The goal is to identify the business opportunities that could come from this new technology and to propose process and IT reconfiguration to fit with RFID. It is made of four steps.

\subsubsection{Phase 3: RFID Project Deployment}

The last phase concerns the validation of the pilot project and the deployments of the technology on the whole supply chain.

\section{Discussion}

The main results of the case study analysis are the following:

- During the project, different CNs are built or broken: the RFiD CN is built upon the project itself, the choice of Casino to externalize the IS part of the project to an ISSP initiated a long-term ISCN working in cooperation with the PCN.

- Some CNs are stable (ISCN and PCN) whereas others are temporary [6], formed only during the project opportunities seeking and pilot project. The project deployment phase transforms a temporary collaboration between the RFiD CN and the IS CN/PCNs mainly based on an innovative project to a business relationship between the Tag Supplier and Casino. 
- The RFiD Temporary CN only invested during the Phases 1 and 2 of the project (Human, Organizational, Physical) and captured value in the last Phase 3 of the project (Brand and Relational above all). Hence, the temporary RFiD CN largely participated to increase the value of the stable $\mathrm{CNs}$

- Value creation (gains) is largely oriented in a $\mathrm{CN}$ logic rather than in an individual logic based on criteria such as size and power. For instance, the ISSP, which is a small company, that is working with CIO in the ISCN reinforced its business relationship with Casino (Relational value) and managed to build a long-term ISCN with CIO, owing to its past business relationships with LSP.

The configuration of temporary and long-term strategic CNs are based on collaborative characteristics such as personal and historical relationships (the information system service provider get used to work with the LSP, the RFiD tag supplier knows personally some CIO department managers) [12], trust and partners competencies. Moreover, the innovative capacity of all the stakeholders of the collaborative network and their willingness to explore new opportunities are important enablers of these configurations. The RFiD technology engenders organizational change and process optimization ([20]; [9]). The RFiD technology also generates intangible benefits [16] but these seem not the same as in manufacturing processes. Knowledge and innovation capacities [17] seem to be the main gains for stakeholders participating in a supply chain temporary CNs. This hypothesis had to be developed in further research through a comparison case-study research design.

\section{References}

1. Bolton, R., Dewey, A., Horstmann, P.: Requirements for Plug and Play, Information Infrastructure Frameworks and Architectures to Enable Virtual Enterprises. In: Proceedings of SPIE 1996, pp. 2-19 (1996)

2. Bowersox, D.J.: The strategic benefits of logistics alliances. Harvard Business Review 68(4), 36-43 (1990)

3. Bowersox, D.J., Closs, D.J., Keller, S.B.: How supply chain competency leads to business success. Supply Chain Management Review 4(4), 70-78 (2000)

4. Boyson, S., Corsi, T.M., Dresner, M.E., Harrington, L.H.: Logistics and the Extended Enterprise: Benchmarks and Best Practices for the Manufacturing Professional. Wiley, New York (1999)

5. Camarinha-Matos, L.M., Afsarmanesh, H.: Collaborative networks: a new scientific discipline. Journal of Intelligent Manufacturing 6, 439-452 (2005)

6. Camarinha-Matos, L.M., Afsarmanesh, H., Galeano, N., Molina, A.: Collaborative networked organizations - concepts and practice in manufacturing enterprises. Computers and Industrial Engineering 57(1), 46-60 (2009)

7. Christopher, M.L.: Logistics and supply chain management. Pitman Publishing, London (1992)

8. Czajkowski, K., Fitzgerald, S., Foster, I., Kesselman, C.: Grid Information Services for Distributed Resource Sharing. In: 10th IEEE International Symposium on High Performance Distributed Computing, pp. 181-184. IEEE Press, New York (2001)

9. Fosso Wamba, S., Lefebvre, L.A., Lefebvre, E.: Integrating RFID Technology and EPC Network into a B2B retail supply chain: a step toward intelligent business processes. Journal of Technology Management and Innovation 2(2), 114-124 
10. GCI, EPC: A Shared Vision for Transforming Business Processes, Global Commerce Initiative (2005), http: / /www . gci-net . org

11. Gilmour, P.: Benchmarking supply chain operations. International Journal of Physical Distribution \& Logistics Management 29(4), 283-290 (1999)

12. Gulati, R.: Does familiarity breed trust? The implications of repeated ties for contractual choice in alliances. Academy of Management Journal 38, 85-112 (1995)

13. Gunasekaran, A., Ngai, E.W.T.: Information systems in supply chain integration and management. European Journal of Operational Research 159(2), 269-295 (2004)

14. Holland, C.: Cooperative supply chain management: the impact of inter-organizational information systems 4(2), 117-133 (1995)

15. Hanman, S.: Benchmarking your firm's performance with best practice. International Journal of Logistics Management 8(2), 1-18 (1997)

16. Ivantysynova, L., Klafft, M., Ziekow, H., Günther, O., Kara, S.: RFiD in manufacturing: the investment decision. In: Pacific Asia Conference on Information Systems, PACIS (2009), http: / /aisel.aisnet.org/pacis2009/41

17. Kogut, B.: The Network as Knowledge: Generative Rules and the Emergence of Structure. Strategic Management Journal 21(3), 405-425 (2000)

18. Loebbecke, C.: Piloting RFID along the supply chain: a case analysis. Electronic Markets 17(1), 29-37 (2007)

19. Loebbecke, C.: Use of innovative content integration information technology at the point of sale. European Journal of Information Systems 16, 228-236 (2008)

20. Niedermann, F., Mathieu, R.G., Morley, R., Kwon, I.W.: Examining RFiD in Supply Chain Management. Communications of the ACM 50(7), 92-101 (2007)

21. Norman, N., Ramirez, R.: From value chain to value constellation: designing interactive strategy. Harvard Business Review 71, 65-77 (1993)

22. Parung, J., Bititci, U.: A metric for collaborative networks. Business Process Management Journal 14(5), 654-674 (2008)

23. Pramatari, K.: Collaborative supply chain practices and evolving technical approaches. Supply Chain Management: An International Journal 12(3), 210-220 (2007)

24. Simatupang, T.M., Sridharan, R.: The collaborative supply chain: a scheme for information sharing and incentive alignment. International Journal of Logistics Management 13(2), 257-274 (2002)

25. Tzeng, S.F., Chen, W.H., Pai, F.Y.: Evaluating the business value of RFiD: Evidence from five case studies. International Journal of Economics 112, 601-613 (2007)

26. Veeramani, D., Tang, J., Gutierrez, A.: A framework for assessing the value of RFID implementation by Tier-one suppliers to major retailers. Journal of Theoretical and Applied Electronic Commerce Research 3(1), 55-70 (2008)

27. Yin, R.K.: Case Study Research: Design and Method. Sage Publication, Thousand Oaks (2003) 